\title{
Displaced Iraqis: Predicaments and Perceptions in Exile in the Middle East
}

\author{
Dawn Chatty and Nisrine Mansour
}

\begin{abstract}
Much has been written about Iraqi refugees in the eight years since the March 2003 Anglo-American invasion of the country. Most of this work tries to understand the refugee crisis which followed from the perspective of "topdown" governmental and institutional factors such as interstate relations, state fragility, and regional insecurity. The key innovation of this paper is that it explores "bottomup" factors. The focus of this paper is on the perceptions, interests, and perceived predicaments of displaced Iraqis themselves as contrasted with the perceptions of them by international players locally based in the Middle East region. As such the paper focuses on factors such as: livelihood strategies, economic engagement, protection rights, and alternatives to refugee/forced migration statuses. By reorienting analysis to local people-based perceptions the paper provides new ways of understanding not only the conditions of protracted displacement but also a broader scope for durable solutions.
\end{abstract}

\section{Résumé}

On a beaucoup écrit au sujet des réfugiés irakiens durant les huit années qui nous séparent de l'invasion anglo-américaine de l'Irak en mars 2003. Une grande partie de cet article tente de mieux comprendre la crise des réfugiés favorisée par des facteurs tels que les relations internationales, la fragilité des états, et l'insécurité nationale et dont la source est au sommet de la société. Cet article innove en explorant aussi les facteurs dont la source est à la base de la société. Ainsi, on se penche sur les perceptions, les intérêts, et les situations difficiles des Irakiens déplacés, en comparaison avec les perceptions qu'ont de ces derniers les acteurs internationaux actifs régionalement au Moyen
Orient. Plus particulièrement, l'article se concentre sur des facteurs tels que la recherche de moyens de subsistance, l'engagement économique, les droits de protection, et les statuts alternatifs à ceux de réfugiés et de migrants forcés. En réorientant l'analyse sur les perceptions des personnes impliquées localement, cet article présente de nouvelles façons de comprendre non seulement les conditions des déplacements prolongés, mais offre aussi une approche plus large permettant de trouver des solutions durables.

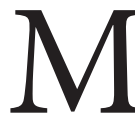

uch has been written about Iraqi refugees in the eight years since the March 2003 Anglo-American invasion of the country. Most of this work tries to understand the refugee crisis which followed from the perspective of "top-down" governmental and institutional factors such as interstate relations, state fragility, and regional insecurity. Top-down approaches tend to be concerned with the three durable solutions (voluntary return, local integration, and resettlement). Hence, top-down analyses and policy implications are confined within this framework and fail to explore other people-centred possibilities for unlocking the crisis. A key innovation of this paper is to prioritize an exploration of the "bottom-up" factors that affect the protracted Iraqi crisis. Here the focus is on the perceptions, interests, and perceived predicaments of displaced Iraqis themselves as contrasted with the perceptions of them by international players locally based in the Middle East region. As such the paper focuses on factors such as: risk and livelihood strategies; social and economic engagement, residence, and protection rights; and the growing reality of alternatives to refugee/forced migration statuses. By reorienting analysis to local people-based perceptions we provide new ways of understanding not only the conditions of protracted displacement and but also a broader scope for durable solutions. Based on fieldwork conducted 
Figure 1. Outflow of refugees to neighbouring countries

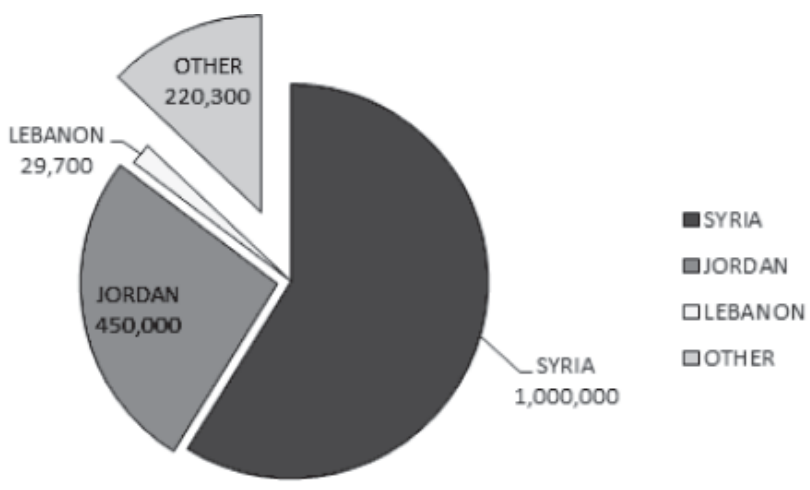

UNHCR, 2009 Global Trends: Refugees, Asylum-seekers, Returnees, Internally Displaced and Stateless Persons, Division of Programme Support and Management, UNHCR, 2010 (last visited 15 June 2011), http://www.unhcr.org.hk/files/unhcr/news/2009\%20 Global\%20Trends.pdf.

between April 18 and May 6, 2011, with locally based international players (UNHCR, IOM, UNRWA, Caritas, and the Canadian Mission), government and national NGO officials (i.e. Red Crescent), as well as with Iraqi asylum seekers, refugees, and temporary guests in Lebanon, Syria, and Jordan this study brings to light the variations in understandings and interpretation between locally-based international players and Iraqi forced migrants themselves.

\section{Background}

The displaced population from Iraq now constitute one of the largest refugee population worldwide. Of nearly 5 million Iraqis displaced by invasion, armed conflict, and insecurity nearly 1.7 million are refugees ${ }^{1}$ and 2.8 million $^{2}$ are internally displaced within their own country. Iraqis are the second-largest group of displaced people seeking asylum in industrialized countries ${ }^{3}$ yet Western countries remain resistant to accepting them as refugees. The spatial separation of previously mixed sectarian and ethnic populations has rendered internal displacement a semi-permanent feature within Iraq, whilst those who have crossed international borders show little inclination to return except in very small numbers. ${ }^{4}$

Most of Iraq's exiles are in the Middle East. Their refuge in the neighbouring countries of Syria, Jordan, and Lebanon is rapidly approaching the five-year mark generally defined as a "protracted crisis." Evidence, so far, suggests that the tolerance of their host governments will continue. This sanctuary, however, is a temporary reprieve and will not go on indefinitely. Unwilling to return and largely unable to emigrate further west, Iraq's refugees are in a perilous situation which needs to be addressed by the Western powers who created this humanitarian crisis. ${ }^{5}$

Iraqi refugees and Internally Displaced People (IDPs) have confounded the West from the beginning of the crisis which culminated in the mass flight of millions of people. Their predicaments and their perceptions have been poorly understood. Their risk strategies for survival and their willingness to remain "unsettled" have also perplexed humanitarian actors. In the aftermath of the invasion of Iraq in March 2003, few Iraqis actually had fled their country. The international aid regime had miscalculated the Iraqi peoples' response to the invasion; the empty emergency camps were dismantled and pre-positioned food and equipment were removed. Three years later in 2006 the West was caught off-guard as hundreds of thousands of Iraqis fled their homes to escape the deadly sectarian violence which had escalated in the February of that year. Nearly 4 million Iraqis fled their homes in 2006 and 2007 with 1 to 1.5 million crossing national borders into Syria and Jordan. The United Nations High Commission for Refugees (UNHCR) and affiliated NGOs raced to set up reception centres and to provide emergency aid.

Despite a reduction in violence and conflict since a peak in 2006-7, Iraq is far from stable and the Iraqi government has not been able to create the conditions for successful return, of either refugees or IDPs. Moreover, displacement is predominantly to urban locations, constituting a new challenge to humanitarian actors seeking to unlock the conditions of protracted displacement. Furthermore, the insecurity currently being felt in Syria has given rise to some return movement. Even if this proves to be of a temporary nature, it will further challenge humanitarian assistance efforts in the region.

Despite a concerted effort over the past four years, UNHCR in Syria has registered only just over 200,000 Iraqis. The reasons these figures are so low can only be guessed. Some Iraqis claim to fear involuntary repatriation to Iraq if they formally register with the UN agency. Others fear returning to a country where the mixed ethnoreligious communities and the legacy of Ottoman tolerance have been wiped away. The targeting of Christians in 2010 through the bombing of Iraqi churches in Baghdad clearly points to the continuing "unmixing" of peoples.

The Iraqi displacement crisis has reached a critical stage. International interest in Iraq is declining. Yet the lack of security, continuing civil conflict, and economic uncertainty make it unlikely that a mass Iraqi return will occur. More likely, Iraqi refugees will remain in neighbouring states under increasingly difficult circumstances. As their savings diminish and their movements into and out of Iraq to make 
money becomes more precarious, it is likely that irregular and long-distance migrations will occur in larger numbers. Unlocking this protracted crisis of displacement requires an understanding of the perceptions of solutions, durable and not so durable, among all stakeholders: Iraqi refugees and exiles, international humanitarian aid agencies, national NGOs, and host governments. The main aims of this study are to link existing research which emphasizes "top-down" governmental and institutional factors such as interstate relations, state fragility, and regional insecurity with an exploration of the "bottom-up" factors. After a brief review of the existing literature, this paper focuses on the perceptions, interests, and perceived predicaments of displaced Iraqis themselves and factors such as: livelihood strategies; social and economic engagement, residence, and protection rights; and the growing reality of alternatives to refugee/ forced migration statuses. By linking a state/regional level analysis with local people-based perceptions (i.e. top-down and bottom-up) we anticipate increasing the potential to provide new ways of understanding not only the conditions of Iraqi displacement but also a broader scope for unlocking them. Responses of international players and national government officials were gathered through interviews with national NGOs and international organizations working on Iraqi resettlement in Lebanon, Syria, and Jordan. At the local level, interviews with Iraqi asylum seekers, refugees, and temporary guests were conducted in all three countries. A total of 21 interviews were conducted during the threeweek period between 18 April and 6 May $2011 .^{6}$

\section{Current Literature on the Displacement of Iraqis}

Since the invasion of Iraq in 2003 and increasingly since the February 2006 bombing in Samarra', it is believed that between 4 and 5 million Iraqis have been forced to leave their homes under conditions of violence and persecution in search of security elsewhere. ${ }^{7}$ Within this context, an estimated but not easily verifiable 2.8 million Iraqis have been internally displaced, and another 2 million have sought refuge abroad. ${ }^{8}$

It is widely understood that forced displacement is not a new phenomenon in Iraq. Displacement was effectuated in several waves that reflect the political trajectory of the country. ${ }^{9}$ Decades of political persecution and devastating sanctions have pushed various groups of Iraqis to flee their homes and become internally displaced or exiled in the region and beyond. Indeed, Iraq has experienced periods of forced migration in the past and it is documented that well over 1 million Iraqis were already internally displaced or living in exile prior to the invasion. ${ }^{10}$

A mass displacement of Iraqis did not occur after the April 2003 invasion; ${ }^{11}$ instead, it was the precipitous breakdown in security in $2006-7$ which prompted the current crisis. The general consensus is that the displaced Iraqis have fled "as a consequence of a conflict in which they have no stake but of which they were made victims." 12 Beyond ethnic or religious identity and minority status, reports cite employment by the United States or other foreign forces, personal wealth, and professional association as additional risk factors. ${ }^{13}$ Compounding the real and perceived threats of violence, countless publications emphasize the widespread impoverishment of people within Iraq, and notably the middle class, as an important factor prompting out-migration. ${ }^{14}$

The Iraqis seeking refuge in neighbouring countries are faced with a hybrid model of protection that is reflected in a precarious legal status. ${ }^{15}$ Syria, Jordan, and Lebanon are not signatories to the 1951 United Nations Convention Relating to the Status of Refugees and lack the domestic legal procedures for dealing with "refugees" or granting asylum. ${ }^{16}$ Initially Syria and Jordan welcomed their "Iraqi brethren" in the tradition of Arab brotherhood, classifying them as "guests" or "temporary visitors" and thus affording them temporary protection. ${ }^{17}$ In January 2007, the UNHCR opted to grant prima facie refugee status to all Iraqi nationals from central and southern Iraq, a designation accepted by the Syrian government but not the Jordanian state. ${ }^{18}$ Nevertheless, the generosity shown by Syria and Jordan to the Iraqi refugees is widely recognized, standing in stark contrast to the negligence of donor countries and Iraq itself. $^{19}$

Many reports have assessed the increasingly burdensome impact of Iraqi refugees on their host countries and drawn analogies to the protracted Palestinian displacement of the 1950 s. $^{20}$ Across the board, reports indicate that local media and citizens blame the Iraqi refugees for their own deteriorating quality of life (rise in real estate prices, traffic jams, price rises, and utilities shortages) and perceive a far larger number of refugees than is actually present. ${ }^{21}$ The governments of Syria and Jordan cite massive expenditures on Iraqi refugees; with Syrian officials claiming costs of over $\$ 1.5$ billion per year and Jordanians quoting \$1 billion, there is little doubt that the Iraqis have induced tangible economic pressures.

That said, the actual picture is more nuanced as excessive blame is placed on Iraqis for issues that existed beforehand, and alongside economic pressures has also come economic growth and investment. ${ }^{22}$ Furthermore, skilled and educated Iraqis with proper work permits substantially contribute to the regional economy. ${ }^{23}$ However, the negative perceptions cannot be ignored, nor can the actual costs incurred by the Syrian and Jordanian governments be dismissed-hostility towards Iraqis based on their perceived or actual burden on society is on the rise. ${ }^{24}$ 
The prospect of refugee return to Iraq has garnered significant attention recently, as improved security within Iraq has received global media coverage. ${ }^{25}$ The government of Iraq has introduced financial incentives to encourage Iraqis to return and has urged the European Union to drop calls for taking in refugees to this effect. ${ }^{26}$ Yet despite these vocal political initiatives, humanitarian and human rights advocates are extremely sceptical, pointing to a perilous security situation and asserting that it would be "reckless" to encourage return before there were genuine and sustained improvements in security and the service provisions of the state. ${ }^{27}$ One small survey by the International Catholic Migration Commission (ICMC) that canvassed the opinions of refugees in Jordan, Lebanon, and Syria demonstrated that none of the 95 Iraqis interviewed believed that Iraq would stabilize in their own lifetime. ${ }^{28}$ At present, the sentiment is that "Iraq's own government should start tending to the displaced population it has, rather than making political on the subject-and at the expense-of refugees." 29

The assistance and accommodation (local integration) of Iraqi refugees in their host countries is an issue of concern among humanitarian organizations. The ambiguous nature of Iraqis' legal status as "guests" prohibits them from gainful employment, pushing them into the exploitative informal sector or, in some cases, "partnerships" with locals. ${ }^{30}$ Even those with legal status (residence permits or temporary visas) struggle to obtain work permits. ${ }^{31}$ There is widespread unemployment, with some Iraqis risking brief and dangerous visits to Iraq to keep their businesses operating, collect pensions and food rations, and other activities for raiding income. ${ }^{32}$ There has emerged a "climate of anxiety and fear of deportations among Iraqis" in some states. ${ }^{33}$ It is the lack of employment opportunities which is cited as one of the main factors imperilling Iraqis' livelihoods and curtailing their ability to afford suitable housing, health care, and education services. ${ }^{34}$

Even though the UNHCR has called upon the international community to do nothing that will compel the refugees to return to Iraq prematurely, ${ }^{35}$ there is very little material that investigates the views and willingness of Iraqis to opt for third-country resettlement. ${ }^{36}$ That said, it has been found that one in five Iraqis in Jordan had concrete plans to resettle in a third country, while 80 percent of the refugee population in Jordan (and Lebanon) do not intend to integrate into the host community, perceiving their stay as temporary. ${ }^{37}$ Family reunification was also found to be a decisive factor when Iraqi families choose to flee from Iraq to neighbouring countries. ${ }^{38}$

Humanitarian and relief agencies, academics, advocacy and policy institutions have sought to elucidate the obstacles that exist to the provision of aid, assistance and protection, repatriation, and the possibilities of third-country resettlement. Yet few studies have paid attention to the motivations of Iraq's exiles for return, resettlement, or extended temporary residence in exile.

\section{Local Level Perceptions: Policy Makers, Practitioners and Iraqi Exiles}

During fieldwork in April and May 2011, we were able to ascertain that while the profiles of Iraqis coming to the attention of the humanitarian agencies in Syria and Jordan consistently included families, Lebanon has witnessed a shift from largely young single men and unaccompanied minors to families seeking third-country resettlement. In the recent period, UNHCR Lebanon has witnessed a surge in registration of Christian families fleeing the wave of violence directed at the Iraqi Christian community in 2010. Policy makers also reported variations in the refugees' motivations for selecting host countries despite a general drive for resettlement. They reported, and this was generally confirmed in our interviews with Iraqis, that those with links to the previous Iraqi regime and thus with slim chances for resettlement tended to opt to go to Syria or Jordan for long-term residence. Lebanon appeared to be sought after as a short-term destination, mainly by Christian refugees seeking resettlement.

All the interviewed policy makers remarked that none of three host states are signatories of the Geneva Convention; each state has adopted different policies for hosting Iraqi refugees. Generally these are entertained with a careful eye to the long-term concerns regarding Tawtiin (integration or naturalization) and the forced migration of Palestinians in the region. Generally, these policy makers reflected that the policies of the Syrian state were largely accommodating of Iraqi refugees-relaxed visa regime, open access to health and education, and easy entry into the informal economy. Jordan, they saw as less accommodating; it had recently tightened its policies regarding movement across its borders due to security claims. Unexpectedly, they felt, Lebanon has adopted the strictest policies in order to counter any claims for naturalization by Iraqis. In their official discourses, both Syria and Jordan consider Iraqis as temporary guests (duyuf) and are reluctant to use the term "refugees." Iraqis themselves do not regard themselves as "refugees" and do not apply the term to describe their conditions.

Beyond the rhetoric, policy makers remarked that each of the three states imposed a different set of legal measures regulating Iraqis' residence, summed up by an initial tourist visa, and a long-term residence permit. Short-term tourist visas were relatively accessible. Since 1 February 2011, Iraqis could get a Syrian visa at the border, while they needed to secure them before arrival to Jordan and Lebanon. Once in 
the host countries, Iraqis could renew these tourist visas for up to a year in most cases. The process was fairly straightforward but could become discretionary when implemented by the border controls. As one Iraqi man explained the tight checkups on his legal status: ${ }^{39}$

Once a civil officer stopped me and asked for my ID, I showed him my UNHCR documents and he insisted on seeing my ID, he said "what is this?", he didn't respect an old man, I told him "I don't have my passport with me, and that all the information is in UNHCR document, if you suspect with the information, call UNHCR they know everything", and he asked me if I was Sunni or Shi'a. He has no right to do so. I told him "we are all Muslims, that is not your business, why are you asking?". This happened to me, I don't know if they do that to others.

Conversely, the residence type of visa was reported to be much harder to secure. Syrian regulations were the most lenient and granted refugees a three-month, renewable residence permit. However the procedures could become complicated. For example, refugees were required to submit official proof of residence through tenancy agreements. In some cases, landlords were reluctant to issue this document because they operated within an informal letting market. ${ }^{40}$ As a result, some Iraqis do not manage to secure residence permits. Alternatively, Iraqis can secure work residence permits, but this incurs high costs and requires a national employer as a guarantor. Most importantly, the work permits are exclusively restricted to certain less skilled and non-professional employment categories.

Within these restrictive legal frameworks, a large number of these Iraqi exiles are undocumented or have had their visa status lapse. Beyond a small portion of wealthy Iraqi families who settled mainly in Jordan, there is a large proportion of middle-class professionals who have become increasingly impoverished due to the protractedness of the crisis. An Iraqi woman, who fled to Lebanon with her family, explains their deteriorating financial situation: ${ }^{41}$

My husband used to be the representative of the Minister of Justice after 2005. [ ... ]. We received threats, calling him a conspirator with the Americans, a conspirator with the Cross, everything of this sort. [ ... ]. I had some gold. I sold it and I came with the money. I used it to leave Iraq [ ... ]. I need food, I need medication. We have nothing.

Iraqis are increasingly turning to the UNHCR and registering as refugees as their savings dry up. However, a sizable proportion of Iraqis prefer not to be identified because they had political links with the former regime. They have little trust in UNHCR's confidentiality standards and fear that their details would be passed on to the Iraqi or US governments. ${ }^{42}$

In Lebanon, Iraqis are considered work migrants. The Lebanese Directorate of General Security has been actively persecuting and detaining over-stayers. Even when the government grants occasional amnesty, it applies only to refugees who entered the country illegally and not those who overstayed their residences. As explained by one policy maker in Lebanon, there are around 100 detainees-found working without the correct papers-among registered refugees at any one time in Lebanon. These tight measures disadvantage Iraqis who do not have the means to finance their stay or find a guarantor employer. As a result, Iraqis in Lebanon are forced to take up informal jobs and are often exploited by employers. For example, a 45-year-old Iraqi arts teacher explains the constraints of his and his family's movement resulting from overstaying their tourist visa: ${ }^{43}$

No, we are not legal. We do not even go out like the people who go out to have fun. We are afraid honestly, even my children. They thank God, I have raised them well. They are young people, 22 and 21 years old, young people. They don't go out, only to work and back home because they are convinced that if one of us eight [him and his family] is caught, we will all be affected.

\section{Low Rate of Voluntary Return}

In all three countries policy makers stated that prospects for voluntary return do not seem promising; very few Iraqis have accepted the voluntary repatriation packages that have been offered. UNHCR recently adopted a deregistration system in an attempt to assess numbers of returnees or onward-migrants. Syria and Jordan offices deactivate files if the refugees do not show up for assistance over a period of six months or a year respectively. UNHCR Jordan saw the numbers of "active" registered refugees drop in the past two years from 60,000 to 32,000 , while the numbers in Syria have remained relatively stable-as Iraqis return to Iraq, others leave. UNHCR Lebanon assumed that voluntary return figures in Lebanon would be very low.

UNHCR does not promote voluntary return and only offers minimal return packages of 100 to 200 US dollars in addition to transportation costs. In Syria fewer than 200 individuals used them in 2010; in Jordan 200 families used them in the past three years; and in Lebanon 42 individuals used them in 2010. NGOs operating similar schemes have also faced little interest in return. Caritas, Jordan, for instance, had two families approach them for assisted return in 2010. One of the families spent a few months in Iraq and then moved back to Jordan shortly thereafter. As a 
result of this low demand, Caritas discontinued the voluntary return schemes.

However, the low official figures of return do not take into account a more fluid and informal circular movement between Iraq and neighbouring countries. A Lebanon-based NGO conducted an internal assessment of the movement of 2,000 Iraqi beneficiary families in 2010. Results showed that 400 families informally returned to Iraq either temporarily or permanently. However, the scope and dynamics of this informal movement are discouraged at the official level as host states' policies vary in terms of promoting or encouraging return. Jordan and Lebanon discourage return or "back and forth migration" by imposing a strict five-year ban on refugees who leave the territory. Syria maintains practically an open door policy with many Iraqis moving back and forth regularly.

All Iraqi refugees-and most of the policy makers and practitioners we interviewed-regarded the precarious security situation in Iraq and the Iraqi government's lack of support as the major reason for the low demand for assisted return schemes. Refugees who returned reported that their neighbourhoods have been segregated along sectarian lines, and experienced ethnic cleansing through threats and confiscation of property: ${ }^{44}$

[My sister and I] used to work as inspectors in the church, we came out of the house in the morning, we saw an envelope in front of the house, there were 3 bullets in it. We were scared to death. We didn't know what to do, but we had to go to church for inspection [ ... ]. But after one month we received another threat a paper in front of our door, threatening us: either we leave or we will be killed. After these threats we understood that we were not threatened because of our work, but most probably because we were Christians, that is why we decided to leave Baghdad. [ ... ]

Many of the refugees we spoke with reported that targeted persecution-the main driver of their flight from Iraq-remained a concern and prevented them from seeking return. These refugees revealed that this category of refugee is diverse and includes Christian and other religious minorities, in addition to those from Sunni and Shi'a backgrounds who were persecuted either because of their affiliation with the former regime, their involvement with the coalition forces, or the mixed marriages they contracted. Sometimes these factors were combined: 45

As I was a university student, then I was a member of the party [... ]. Our loyalty is for the country. We started receiving threats. And then we decided to leave, my father and I only. We left without anything. Only with the clothes I was wearing. We felt like we were thieves. I don't know what to say. People were threatening

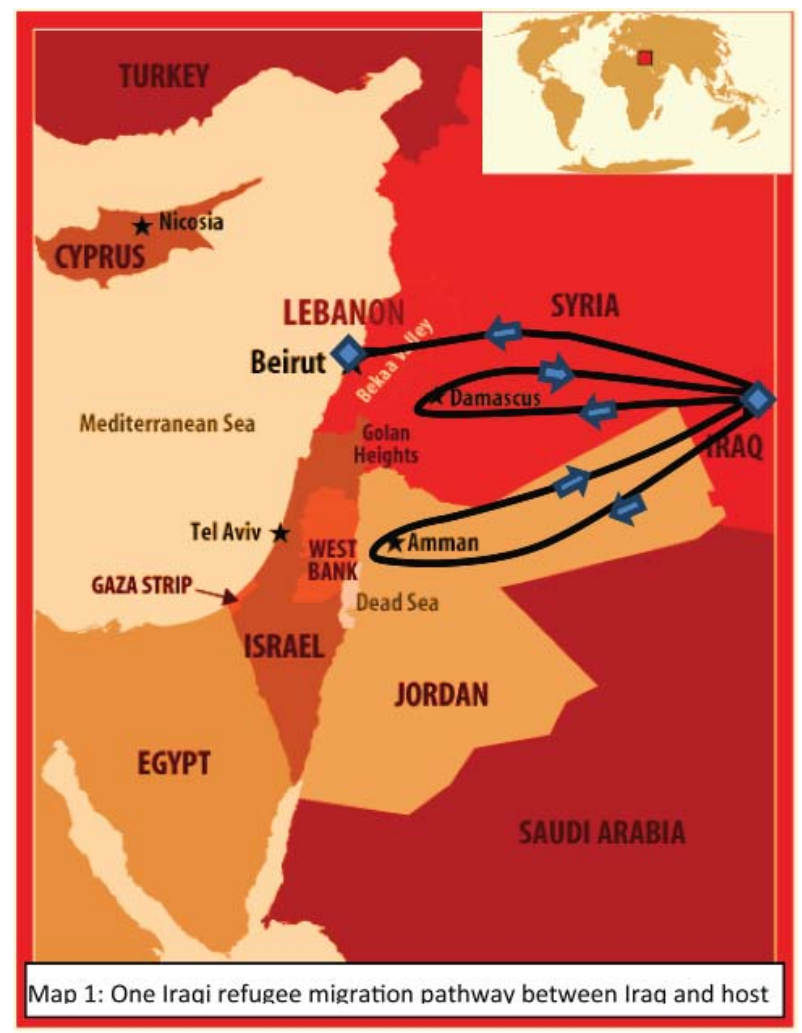

us for what? And you didn't do anything. Only because you were loyal to the nation? Only because you were a party member? So we had to leave. My family was divided. My mother as a Shi'a went back to her family, to her parents. She had to. She was forced to [ ... ]. It was hard. So we decided to leave.

Overall it appears that the reduction in reported violence in Iraq in the last few years challenges the classical definitions of a "refugee" as one fleeing but not returning. The growing circularity of migration among Iraqis in the Middle East challenges these ideas and definitional assumptions. According to one policy maker in Jordan, the relative reduction in violence increased the movement of Iraqis who returned home for specific reasons such as to check on their relatives, sell their assets, collect their pensions, and assess the security situation, first-hand. These return visits, he added, do not imply that Iraqi refugees feel safe to return permanently. He explained further, "As far as we can tell they go in, do their task and come out, and if you ask them about the situation, they have taken a risk, it's a calculated risk. For some people the risk hasn't paid off, they got killed." 46

As a result, many Iraqis return-temporarily-to Iraq without informing the organizations involved. For example, 
some male heads of households go on their own to assess the situation, and later relocate their families accordingly.

\section{Ongoing Local Accommodation in Lieu of Official Local} Integration

Our interviews indicate that the boundaries between longterm humanitarian assistance in protracted refugee situations and the prospects of "local integration" are blurred. The sensitivity to the protracted Palestinian refugee crisis has meant that the term "integration" is generally rejected by policy makers, practitioners, and Iraqis alike. However, the case of Iraq's exiles and refugees suggests that a continuous process of accommodation is taking place locally, with important implications in terms of the relations between host and refugee communities.

UNHCR has adapted a variety of forms of assistance in each country to respond to what it perceives is the scope of the refugee crisis in the state. Iraqi refugees are provided with food and cash distribution in Syria, cash distribution in Jordan, and food coupons in Lebanon. In Jordan, for example, UNHCR provides cash assistance to almost half of the active registered refugees $(13,500)$, while some service providers such as Caritas reported steady numbers of Iraqi beneficiaries at around 8,000. In the three countries, NGOs provide skills and language training to men and women: technical training such as computer maintenance for men; while training for women focused on conventional skills such as hairdressing and sewing. In Lebanon, several NGOs provide legal services for detainees and assistance in securing work permits.

Despite the restrictive legal frameworks and the rejection of "local integration" as a durable solution, Iraqi exiles reported an ongoing process of accommodation in the three countries. This process was the outcome of new patterns of inter- and intra-social relations between host and refugee communities and within Iraqi communities. This ongoing accommodation was not problem-free as tensions between local and refugee communities were reported. While refugees complained about meagre entitlements, locals felt threatened by competition over job opportunities, social provision, the rise in cost of living, and security.

\section{Third-Country Resettlement}

Third-country resettlement of Iraqis has faced many challenges in terms of burden sharing and refugees' expectations. From the start of the crisis, Western countries' responses have been unpredictable and varied. Their roles and responsibilities with regard to the Iraq War do not seem to have played a part in determining national resettlement quotas for Iraqi refugees. In the past few years, quotas for resettlement have dropped dramatically, mainly due to the withdrawal of European countries from the program. As one policy maker in Syria explained, "Iraq is the black spot that people want to sweep under the carpet and forget about. But the reality for Iraqi refugees is quite crisp." ${ }^{37}$

Iraqi respondents felt that the Western states had an obligation to fulfill as an outcome of their roles in the war on Iraq. The majority of Iraqi refugees are reportedly interested in third-country resettlement. Whether due to general insecurity in Iraq, or targeted persecution, Iraqi refugees were creating transnational social networks as a way of ensuring their safety and reducing the risks they and their families face in exile. Dispersion along a vast transnational network including the US and Canada was increasingly common. ${ }^{48}$ The case of one refugee in Lebanon illustrated this point. He was one of four siblings who were all dispersed in various countries at various periods in the past 15 years. He was based in Lebanon, with one brother in Jordan, another in Malta, and a sister in the US. ${ }^{49}$

Policy makers we interviewed clearly associated thirdcountry resettlement with the national economic, social, and political interests of the Western states. As one senior diplomat explained: ${ }^{50}$

Resettlement is not asylum. No country has an obligation to resettle a refugee from a third-country. So it is not about providing protection in the legal sense. [ ... ] And every country that I am aware of, including Canada has criteria based on whether or not you need protection as a refugee, but there are also some criteria that represent other national policy objectives. [ ... ] Some of these criteria involve protecting the safety and security of Canadians.

Policy makers were at times informally critical of selective criteria that disqualified various categories of Iraqi refugees. For example, several states exclude nationals associated with the former regime. This was seen as a particularly problematic exclusion as many of the middle-class professional Iraqi exiles were required to belong to the Baath party in order to work under the former regime. In some cases, Western resettlement criteria are set according to sectarian affiliation. Germany and France were reported to be interested in resettling Christian refugees only, an issue opposed by UNHCR. ${ }^{51}$

The resettlement selection process also disadvantages the widespread Middle Eastern preference for extended families and households. Most resettlement missions are directed at nuclear families with children less than 18 years of age. This excludes adult children who usually live with their parents and elderly relatives such as grandparents. These criteria add to the pressure on Iraqis who face leaving their family members behind. One elderly Iraqi in Jordan said: ${ }^{52}$ 
Map 2. One family, transnational destination: Migrations of the extended family of an Iraqi respondent (REFSYR1)

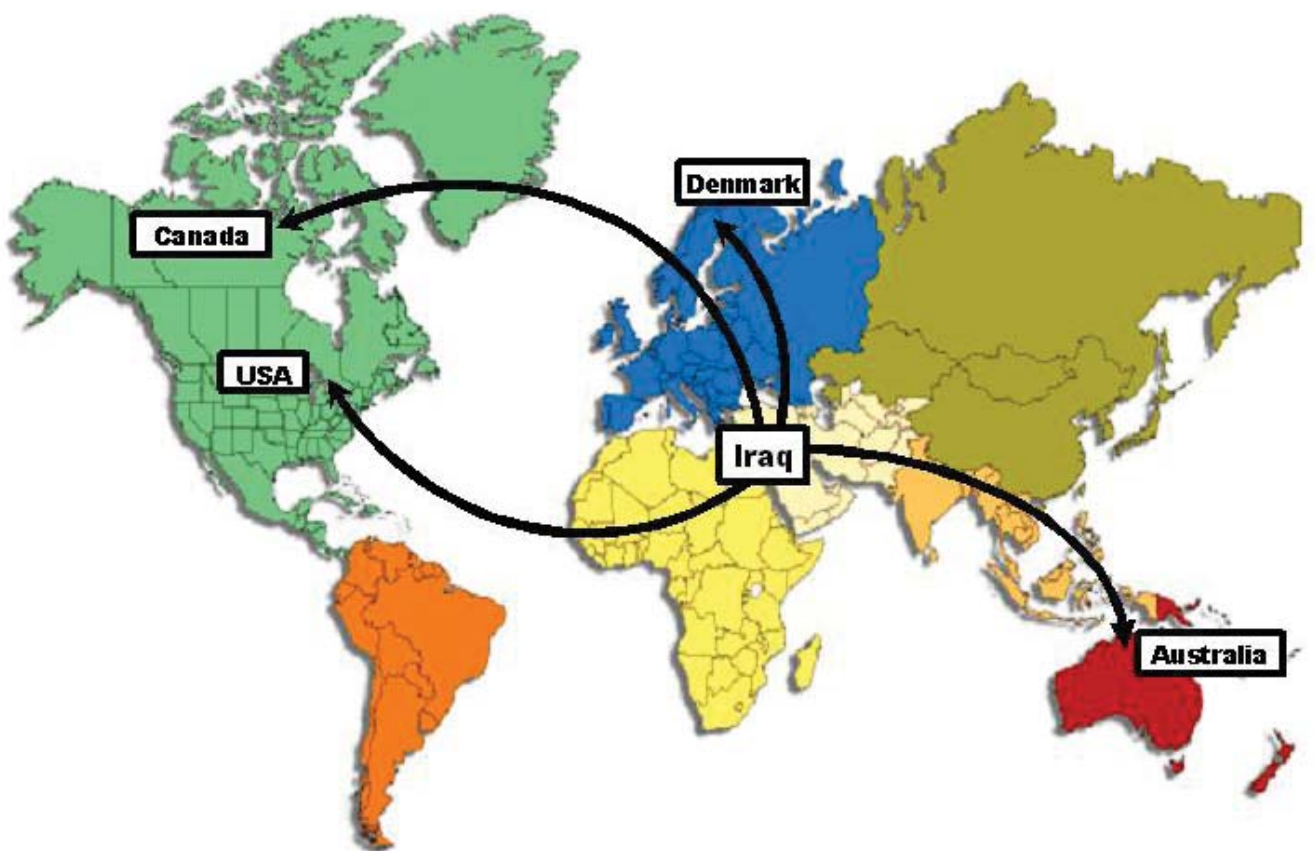

As for the USA, I told them, I have a son in Syria who submitted his papers there. He is waiting his turn. If they allow me to go with my son to USA I will go. But I do not want to die alone, and be buried by others from another religion. I want to travel with my son; it is very difficult for someone of my age to live alone in America.

Policy makers believed Iraqi refugees to be quite knowledgeable about the criteria for resettlement of various countries. Interviews with refugees, however, contradicted these assumptions. We found that refugees constructed knowledge of the conditions and criteria of resettlement schemes based on conflicting information circulated in their social networks. Refugees get caught up a cycle of trial and error and often resort to informal channels leading them to use irregular routes of migration to Western countries and seek asylum in them. ${ }^{53}$ Furthermore, refugees indicated that they did not receive regular updates about the status of their application. In Lebanon for instance, waiting times can go over a year without notification. This issue was particularly distressing for refugees who were "left hanging" for extended periods. One refugee in Lebanon likened the resettlement process to a matter of life and death: ${ }^{54}$ "One is waiting like hanging between the earth and the sky. If the string breaks you either fall on the ground and someone picks you up, or you go to the sky."

Policy makers also pointed out that the conditions of resettlement at the country of destination included challenges in terms of expectations of self-reliance, adaptation, and support. While 70 percent of registered refugees were university graduates, they reported that refugees found it hard to settle for menial or less qualified jobs in their resettlement country. ${ }^{55}$ Refugees were also subjected to anxiety and stress in certain contexts as support packages varied from country to country. For example, the US offered resettled refugees a support package for six months, after which time they were expected to work and repay it as their "loan." As a result, many resettled Iraqis, especially the older generation and some vulnerable women, were giving up and returning to the host countries. ${ }^{56}$

\section{Conclusion: Constraints, Innovations, and Accommodations}

Three broad areas emerged from these local-level interviews in the exploration of the conditions and predicaments as well as possibly innovative solutions in this protracted crisis: reconceptualizing the term "refugee"; clarifying asylum and resettlement criteria; and encouraging local accommodation.

Policy makers, practitioners, and Iraqis we interviewed considered that a liberalized view of refugee movement was needed. The perceptions of policy makers reflected a nuanced understanding of the realities of the protracted refugee crisis. They did not completely subscribe to the dominant humanitarian framework of the three classical solutions. Equally they held a balanced view of the issues faced by refugees, agreeing with some and contesting others. They all regarded security in Iraq as the major constraint 
hindering Iraqis' return to the country. They also recognized that the fluid movement of Iraqis back and forth to Iraq was an important mechanism for improving life opportunities and reducing family risk. Relaxing regulations on border crossing across the three countries was considered potentially useful for the long-term solution to the crisis as it would allow members of refugee households to return temporarily and get a sense of the situation in Iraq. This mobility was a common feature of Iraqi exiles' transnational networks, as one refugee mapped out: ${ }^{57}$

My parents are abroad; [ ... ] my siblings are abroad. My brother is a naturalised American, and my mother needs a few more months to get it. My brother and sister are in Canada. My uncles are in Michigan. My uncle is in Australia; my cousin in Australia. My cousin is in Denmark and so on, we are an international family and you can find us everywhere.

On the ground, international policy makers recognized the need to clarify and share information related to the criteria of resettlement. Several policy makers mentioned that the lengthy and unclear procedures of third-country resettlement kept "refugees hanging." 58 Some suggested the creation of a user-friendly manual of the requirements and criteria of resettlement would be valuable for use across all three countries. ${ }^{59}$

Policy makers also recognized the heavy baggage around ideas of local integration-a term widely rejected by the host states. They all recognized that there was a growing category of Iraqis who were becoming "stuck" in host countries. This group included some of the most vulnerable categories such as the elderly left behind after nuclear family resettlement, or less skilled young adults. For this group-especially the young-policy makers were concerned that work permits or a relaxation of labour laws should be considered by the host states to lessen Iraqi refugees' dependency on humanitarian aid. Refugees echoed these concerns. As one refugee in Lebanon stated: 60

If I legalise my situation, I can go and come back as I want. I would be able to work in bigger firms. Now I have a computer maintenance diploma, and I know a lot about these things. I went and applied to a company in Jounieh. They fix satellites and things like that. They needed a work permit. And the salary was good salary, more than $\$ 1,000$ [ ... ]. If I had a residency permit, I would be able take up this job. But instead, I am working as a house keeper in a hotel. Is that a job for me? No it's not, but what can I do?

The "refugees" of the Iraqi crisis do not fit with Western conceptualizations of refugee law. Their flight has been a steady outflow for more than a decade, peaking in
2006-7. The migration is not "one-way"; it is often circular and involves movement in and out of Iraq as well as across wider transnational networks in the Middle East and further afield. This mobility is a result of the protractedness of their situations and includes a strategy of managing life risks by dispersal of family members along pre-established social networks whenever possible. Iraqi mobility is part of the reality of this protracted refugee crisis. It needs to be recognized as a risk management strategy for refugees for whom the three classic durable solutions are largely inapplicable. Unfortunately this mobility is often looked at sceptically by many in the humanitarian aid regime as it raises questions regarding how well Iraqis fit into the "category" of refugee.

\section{Notes}

1. United Nations High Commissioner for Refugees (UNHCR), UNHCR Syria Update. UNHCR, May 2008, last visited 7 July 2008, http://www.un.org.sy/publications /UNHCR\%20Syria\%20Update\%20May\%202008.pdf.

2. Internal Displacement Monitoring Centre (IDMC), 2009, http://www.internal-displacment.org/idmc/website /countries.nsf; IDMC, 2010, Global Overview of Trends and Developments in Internal Displacement, http://www .internal-displacment.org/idmc/website/countries.nsf.

3. UNHCR, Report on Asylum Levels and Trends in Industrialized Countries, UNHCR, 2009, http://www.unhcr.org /pages/49c3646c4d6.html.

4. P. Marfleet and D. Chatty, Iraq's Refugees: Beyond 'Tolerance,' RSC Forced Migration Policy Brief no. 4 (Oxford: Refugee Studies Centre, University of Oxford, 2003).

5. Ibid.

6. Preliminary contacts for interviews were established through the offices of the UNHCR. Once in-country, a snowball technique was used to arrange for further policymaker and practitioner interviewing. Interviews with Iraqis were arranged purposively, with the actual selection of interviewees made by the NGO or UN Agency staff.

7. International Crisis Group (ICG), Failed Responsibility: Iraqi Refugees in Syria, Jordan and Lebanon, 10 July 2008, 77: 1-42; The Middle East Institute (MEI), Iraq's Refugee and IDP Crisis: Human Toll and Implications, Viewpoints Special Edition, Washington, DC, MEI, 2008, last visited 17 June 2011, http://www.mei.edu/Publications /WebPublications/Viewpoints/ViewpointsArchive/ tabid/541/ctl/Detail/mid/1623/xmid/190/xmfid/11/ Default.aspx; Amnesty International (AI), Iraq, Rhetoric and Reality: The Iraqi Refugee Crisis, London, AI Index: MDE 14/011/2008, London, 15 June, 2008a, 1-66; UNHCR, Global Trends, UNHCR, 2008, last visited 10 June 2011, http://www.unhcr.org/4a375c426.html.

8. AI, Iraq: Suffering in Silence: Iraqi Refugees in Syria, 12 May 2008, MDE 14/0110/2008, (last visited 26 July 2012), http:// 
www.unhcr.org/refworld/docid/4847a4841f.html; International Organization for Migration (IOM), Assessment of the Psychosocial Needs of Iraqis Displaced in Jordan and Lebanon, IOM Survey Report, IOM, Amman and Beirut, February 2008; ICG, Failed Responsibility, 77: 1-42; International Rescue Committee (IRC), Five Years Later, A Hidden Crisis, Report of the IRC Commission on Iraqi Refugees, March 2008; UNHCR, Asylum Levels 2009.

9. See G. Chatelard, O. el-Abed, and K. Washington, Protection, Mobility and Livelihood Challenges of Displaced Iraqis in Urban Settings in Jordan, International Catholic Migration Commission, 2009 (last visited 21July 2009), http://www.icmc.net/pubs/protection-mobility-and -livelihood-challenges-displaced-iraqis-urban-settings -jordan; G. Chatelard, "A Quest for Family Protection: The Fragmented Social Organisation of Transnational Iraqi Migration" (keynote speech to the conference Displacement and Dispossession: Forced Migration in Africa and the Middle East, British Academy, London, 28 March 2008; P. Marfleet, "Iraq's Refugees: 'Exit' from the State," International Journal of Contemporary Iraqi Studies 1, no. 3 (2007): 397-419.

10. Chatelard, "A Quest for Family Protection"; Middle East Report (MERIP), Displaced, Iraqis in Jordan and Syria (MERIP 37, no. 3 (2007): 2-24, 22; Human Rights Watch (HRW), "Iraqi Refugees, Asylum Seekers and Displaced Persons: Current Conditions and Concerns in the Event of War," Human Rights Watch Briefing Papers, 13 February 2003, 1- 25; for detailed statistics see D. Romano "Whose House Is This Anyway? IDP and Refugee Return in PostSaddam Iraq," Journal of Refugee Studies 18, no. 4 (2005): 430-53.

11. D. Chatty, "'Operation Iraqi Freedom' and Its Phantom Million Iraqi Refugees," Forced Migration Review (18 September 2003): 51.

12. ICG, Failed Responsibility, 1.

13. ICG, Failed Responsibility; MEI, Iraq's Refugee; A. al-Khalidi, S. Hoffmann, and V. Tanner, Iraqi Refugees in the Syrian Arab Republic: A Field-Based Snapshot (Washington, DC: The Brookings Institution-University of Bern Project on Internal Displacement, 2007.)

14. AI, Iraq, Rhetoric and Reality; al-Khalidi et al., Iraqi Refugees; “Iraq's Displacement Crisis: The Search for Solutions,' Special Issue, Forced Migration Review (FMR) (June 2007): 1-52, http://www.fmreview.org/iraq.htm; J. Sassoon, The Iraqi Refugees: The New Crisis in the Middle East (London and New York: I.B. Tauris, 2009). See also MEI, Iraq's Refugee, 41; al-Khalidi et al., Iraqi Refugees; FMR, Iraq's Displacement Crisis; F. Marfleet, "Iraq's Refugees: 'Exit' from the State," International Journal of Contemporary Iraqi Studies 1, no. 3 (2007): 397-419; J. Steele, “The Iraqi Brain Drain," The Guardian, 24 March 2006, last visited June 2006, http://www.guardian.co.uk/world/2006/mar/24 /iraq.jonathansteele.
15. AI, Iraq, Rhetoric and Reality; ICG, Failed Responsibility; MERIP, Displaced.

16. G. Chatelard, K. Washington, and O. el-Abed, An Assessment of Services Provided for Vulnerable Iraqis in Jordan, Report commissioned by AUSTCARE- Middle East Regional Office, Ramallah (September 2007, updated February 2008), 1-38; Human Rights Watch (HRW), "Jordan: The Silent Treatment: Fleeing Iraq, Surviving in Jordan," Human Rights Watch 18, no. 10 (November 2006); HRW, "Rot Here or Die There: Bleak Choices for Iraqi Refugees in Lebanon," HRW 19, no. 8 (November 2007); AI, Iraq, Rhetoric and Reality.

17. ICG, Failed Responsibility; G. Chatelard, "A Quest for Family Protection: The Fragmented Social Organisation of Transnational Iraqi Migration" (keynote speech to the conference "Displacement and Dispossession: Forced Migration in Africa and the Middle East," British Academy, London, 28 March 2008); P. Fagen, Iraqi Refugees: Seeking Stability in Syria and Jordan (Doha: Institute for the Study of International Migration, Georgetown University School of Foreign Service in Qatar, 2007), 1-39; FMR, Iraq's Displacement Crisis.

18. A. Harper, "Iraq's Refugees: Ignored and Unwanted," International Review of the Red Cross 90, no. 869 (March 2008): 169-90; P. Fagen, Seeking Stability, 5-6; L. Al-Zubaidi and H. Wimmen, No Place Home: Iraqi Refugees between Precarious Safety and Precipitous Return (Beirut: Henrich Böll Stifting, 2008).

19. Harper, "Iraq's Refugees"; ICG, Failed Responsibility; AI, Iraq, Rhetoric and Reality; HRW, Silent Treatment.

20. ICG, Failed Responsibility, 11; Fagen, Seeking Stability, 6; alKhalidi et al., Iraqi Refugees, 40; FMR, Iraq's Displacement Crisis.

21. Office for the Coordination of Humanitarian Affairs (OCHA), Consolidated Appeals Process (CAP): Mid-Year Review of the Appeal 2009 for Iraq and the Region, 2009, OCHA, last visited 22 July 2009, http://reliefweb.int/rw/rwb .nsf/db900sid/AMMF-7TYT9E?OpenDocument\&cc=irq; J. Kurtzer, Iraq: Keeping Our Focus, 2009, last visited 22 July 2009, www.refugeesinternational.org/blog/iraq-keeping -our-focus; A. Evans Barnes, "Realizing Protection Space for Iraqi Refugees: UNHCR in Syria, Jordan and Lebanon" (UNHCR, New Issues in Refugee Research, research paper 167, 2009), last visited 29 June 2009, http://www .unhcr.org/49813ab2.html; ICG, Failed Responsibility, 15; K. O'donnell and K. Newland, The Iraqi Refugee Crisis: The Need for Action (Washington, DC: Migration Policy Institute, 2008); Fagen, Seeking Stability; al-Khalidi et al., Iraqi Refugees, 40.

22. ICG, Failed Responsibility, 13; Fagen, Seeking Stability; N. Seeley, "For Some Iraqi War Refugees, Business Is Booming," The Christian Science Monitor, 10 June 2008, last visited October 2008, http://www.csmonitor.com/2008/0611 /p07s01-wome.html.

23. IRC, Five Years Later, 7. 
24. Barnes, "Realizing Protection Space"; R. Leenders, "Iraqi Refugees in Syria: Causing a Spillover of the Iraqi Conflict?" Third World Quarterly 29, no. 8 (2008): 1563-84; S. K. Lischer, "Security and Displacement in Iraq: Responding to the Forced Migration Crisis," International Security 33, no. 2 (Fall 2008): 95-119; ICG, Failed Responsibility; MERIP, Displaced; Fagen, Seeking Stability, 19; al-Khalidi et al., Iraqi Refugees.

25. E. Ferris and K. Stoltz, Minorities, Displacement and Iraq's Future, Washington D.C., The Brookings Institution, 2008 (last visited 20 June 2009), http://www.brookings.edu /papers/2008/1223_minorities_ferris.aspx; Heinrich Böll Stiftung (HBS), What Can Europe Do in Iraq? Recommendations for a New U.S.-European Collaboration, Publication series on Democracy, vol. 11 (Berlin: Heinrich Böll Stiftung, 2009), last visited 30 June 2009, http://www.boell.de /publications/publications-6137.html; UNHCR, UNHCR revises guidelines for Iraqi asylum claims, UNHCR, 2009 (last visited 30 June 2009), http://www.reliefweb.int/rw /rwb.nsf/db900SID/LSGZ-7RRDVC?OpenDocument; AI, Iraq, Rhetoric and Reality; ICG, Failed Responsibility.

26. IRIN, "Iraq: Refugees Could Fuel Regional Instability, Experts Say," IRIN News, 20 June 2008, last visited 7 July 2008, http://www.irinnews.org/Report.aspx?ReportId=78841; Reuters, "Iraq Still Too Fragile to Take Back Refugees," 2 June 2009, last visited 11 October 2009, http://www.reuters .com/article/homepageCrisis/idUSL2602950._CH_.2400.

27. UNHCR, UNHCR revises guidelines; ICG, Failed Responsibility, ii; AI, Iraq, Rhetoric and Reality.

28. F. Riller, Observations and Recommendations on the Resettlement Expectations of Iraq Refugees in Lebanon, Jordan and Syria, ICMC, 2009, last visited 21 July 2009, http:// www.icmc.net/pubs/observations-and-recommendations -resettlement-expectations-iraqi-refugees-lebanon-jordan -and-sy.

29. Chatelard et al., Protection.

30. See al-Khalidi et al., Iraqi Refugees, 35; IOM, Psychosocial Needs; ICG, Failed Responsibility; Fagen, Seeking Stability.

31. Chatelard et al., Assessment of Services.

32. IRC, Five Years Later, 6; AI, Iraq, Suffering in Silence, 7.

33. Chatelard et al., Assessment of Services, 11.

34. AI, Iraq, Rhetoric and Reality; IOM, Psychosocial Needs, 49; ICG, Failed Responsibility; MERIP, Displaced; UNHCR, Iraq Bleeds: Millions Displaced by Conflict, Persecution and Violence, REFUGEES, 2007, 146 (2): 1-31 (last visited 7 July 2008), http://www.unhcr.org/publ/PUBL/4614f5802.pdf.

35. UNHCR, UNHCR revises guidelines.
36. Riller, Observations.

37. Ibid.

38. Chatelard et al., Protection.

39. Interview with Iraqi refugee (REFJOD5) in Amman, Jordan, 3 May 2011.

40. Interview with policy maker (PMSYR2) in Damascus, Syria, 18 April 2011.

41. Interview with Iraqi refugee (REFLEB1) in Beirut, Lebanon, 5 May 2011.

42. Interviews with policy makers in Syria, Jordan.

43. Interview with Iraqi refugee (REFLEB3) in Beirut, Lebanon, 5 May 2011.

44. Joint interview with Iraqi refugee family (REFJOD1, REFJOD2, REFJOD3) in Amman, Jordan, 3 May 2011.

45. Interview with Iraqi refugee (REFLEB2) in Beirut, Lebanon, 5 May 2011.

46. Interview with policy maker (PMJOD1) in Amman, Jordan, 2 May 2011.

47. Interview with policy maker (PMSYR3) in Damascus, Syria, 20 April 2011.

48. A. Monsutti, "Afghan Migratory Strategies and the Three Solutions to the Refugee Problem," Refugee Survey Quarterly 27, no. 1 (2008): 58-73.

49. Interview with REFLEB2.

50. Interview with senior diplomat (SENDIP1) in Damascus, Syria, 18 April 2011.

51. Interview with PMSYR3.

52. Interview with REFJOD5.

53. Interview with PMSYR2.

54. Interview with REFLEB3.

55. Interview with PMJOD4.

56. Interview with policy maker (PMJOD5) in Amman, Jordan, 4 May 2011.

57. Interview with Iraqi refugee (REFLEB2) in Beirut, Lebanon, 5 May 2011.

58. Interview with PMLEB4.

59. Interview with PMSYR3.

60. Interview with REFLEB2.

Dawn Chatty is Director of the Refugee Studies Centre and Professor of Anthropology and Forced Migration in the Oxford Department of International Development, University of Oxford. Nisrine Mansour is a Research Fellow in the Refugee Studies Centre. 
(c) Dawn Chatty and Nisrine Mansour, 2011. This open-access work is licensed under a Creative Commons Attribution-NonCommercial 4.0 International License, which permits use, reproduction and distribution in any medium for non-commercial purposes, provided the original author(s) are credited and the original publication in Refuge: Canada's Journal on Refugees is cited. 